\title{
Diversity and conservation status of bromeliads from Serra da Piedade, Minas Gerais, Brazil ${ }^{1}$
}

Diversidade e estado de conservação das bromélias da Serra da Piedade, Minas Gerais, Brasil

\author{
Andréa Rodrigues Marques ${ }^{2,5}$, José Pires de Lemos Filho ${ }^{3}$ \& Rubens Custódio da Mota ${ }^{4}$
}

\begin{abstract}
The Espinhaço Mountain Range in Minas Gerais state in southeastern Brazil is a center of endemism of the Bromeliaceae, mainly in campo rupestre montane vegetation that grows under rigorous edaphoclimatic conditions. This study sought to improve our knowledge of the Bromeliaceae from Serra da Piedade in the extreme southern portion of the Espinhaço Mountain Range where ironstone outcrops predominate. Conservation status and spatial distribution of these plants were analyzed as well as floristic similarities with other regions with rocky outcrops. Twenty-five bromeliad species were found in Serra da Piedade, with the subfamily Tillandsioideae being the best represented. Twenty-seven percent of the species were exclusive to campo rupestre environments, while $73 \%$ occurred both on outcrops and in forest habitats. The bromeliads in the study area merit special attention as two species are considered vulnerable (Racinaea aerisincola and Vriesea minarum), five are endangered, and three are critically endangered. Low Jaccard index values indicated dissimilarities between the bromeliad floras in different localities of quartzite and ironstone outcrops within the Espinhaço Mountain Range. Serra da Piedade has a distinct bromeliad flora that is threatened by mining activities and illegal harvesting and requires immediate measures to help guarantee conservation.
\end{abstract}

Key-words: conservation, campos rupestres, ironstone outcrops, Bromeliaceae.

\section{Resumo}

A Cadeia do Espinhaço em Minas Gerais, sudeste do Brasil, é reconhecida como centro de endemismo de Bromeliaceae, principalmente nos campos rupestres, onde as condições edafo-climáticas são severas. O objetivo deste estudo foi estender o conhecimento sobre as Bromeliaceae da Serra da Piedade localizada no extremo sul da Cadeia do Espinhaço onde predomina a ocorrência de afloramentos ferruginosos. O estado de conservação e a distribuição espacial foram analisados, bem como, a similaridade florística de bromélias entre diferentes localidades com afloramentos rochosos. Na Serra da Piedade foram encontradas 25 espécies, sendo a subfamília Tillandsioideae a mais representativa. Dentre as espécies, $27 \%$ são exclusivas de campos rupestres e $73 \%$ ocorreram tanto nos afloramentos rochosos quanto nos habitats florestais. As espécies de bromélias na área de estudo necessitam de muita atenção, pois duas espécies estão vulneráveis (Racinaea aerisincola e Vriesea minarum), cinco espécies em perigo e três espécies em perigo crítico de extinção. Os baixos valores do índice de Jaccard apontaram uma dissimilaridade entre a flora de bromélias de diferentes localidades com afloramentos quartzíticos e ferruginosos da Cadeia do Espinhaço. A Serra da Piedade apresenta uma flora de bromélias exclusiva, a qual está ameaçada pela mineração e extrativismo, sendo necessária uma ação imediata para sua conservação.

Palavras-chave: conservação, campos rupestres, afloramentos ferruginosos, Bromeliaceae.

\footnotetext{
${ }^{1}$ Part of the Doctoral Thesis of the first author developed in Ecology, Conservation and Management of Wildlife Graduate Program, Universidade Federal de Minas Gerais, Minas Gerais, Brazil.

${ }^{2}$ CEFET/MG, Depto. Engenharia Ambiental, Av. Amazonas 5253, 30480-000, Belo Horizonte, MG, Brazil.

${ }^{3}$ UFMG, ICB, Depto. Botânica, Av. Antônio Carlos 6627, 31270-110, Belo Horizonte, MG, Brazil.

${ }^{4}$ Instituto Cultural Inhotim, R. B 20, 35460-000, Brumadinho, MG, Brazil.

${ }^{5}$ Corresponding author: andrearmg@gmail.com
} 


\section{Introduction}

The Espinhaço Mountain Range extends with a N-S orientation for approximately 1100 $\mathrm{km}$ through the states of Minas Gerais and Bahia, where it is known as the Chapada Diamantina Range (Harley 1995). The unique vegetation there, known as campos rupestres (rupestrian vegetation on rocky outcrops), typically grows at altitudes above $800-900 \mathrm{~m}$ and is a very important habitat for many species of the Brazilian fauna and flora, especially the plant family Bromeliaceae (Versieux \& Wendt 2007).

Campo rupestre vegetation in the Espinhaço Mountain Range is a mosaic of various distinct plant communities with different floristic affinities and it is known to be a center of diversity and endemism for $30 \%$ of its flora, with many rare plants (Harley 1995; Giulietti et al. 1987, 2000, 2005; Alves et al. 2007; Conceição et al. 2007; Jacobi et al. 2007; Rapini et al. 2008). It is found mainly on quartzite/sandstone outcrops within the Cerrado (Brazilian savanna) and Caatinga (dryland) biomes (Conceição et al. 2007; Martinelli 2007; Scarano 2007; Alves \& Kolbek 2009), comprising dense herbaceous vegetation with low trees where the soils are deeper; riparian forests occur along watercourses, and forest patches, known as "capões", occur on hillsides and on hilltops (Pirani et al. 1994; Versieux \& Wendt 2007; Versieux et al. 2010).

However, in the extreme southern portion of the Espinhaço Mountain Range, this vegetation type is associated with iron oxide deposits known as canga (Rizzini 1997, Jacobi \& Carmo 2008) in a region called the Quadrilátero Ferrifero (Iron Quadrilateral). These ironstone outcrops are extremely rigorous for plant establishment, with hard substrate; thin, acidic, dry and nutrient poor soils (Haley 1995; Giulietti et al. 1997; Sano \& Almeida 1998), with high levels of heavy metals (Bueno 1992; Teixeira \& Lemos-Filho 2002). Climatic conditions, such as a high incidence of UV light, high diurnal temperature variations, heavy winds, and low relative humidity likewise make plant growth more difficult (Giulietti et al. 1997).

The Serra da Piedade, located in the Iron Quadrilateral, at the Minas Gerais portion of the Espinhaço Mountain Range, is reported as a priority area for biodiversity conservation (MMA, 2000). Minas Gerais is one of the most important areas in Brazil for endemic bromeliads (Versieux \& Wendt 2007; Versieux et al. 2008, 2010; Versieux
2011), corresponding to almost $9 \%$ of the total number of species for the entire family. There is an urgent need for effective regional conservation strategies that can help protect and conserve the local biological heritage, especially in the Iron Quadrilateral- which is subject to open pit mining (Jacobi et al. 2011). Within this context, we posed the following questions: (1) how many bromeliad species grow in Serra da Piedade, and what local vegetation are they associated with? (2) what are the conservation status and spatial distributions of the bromeliad species found in this region? (3) is the bromeliad flora of Serra da Piedade comparable to the flora from other locations on rocky outcrops of the Espinhaço Mountain Range?

\section{Material and Methods}

Serra da Piedade is located in the southeastern region of the Espinhaço Mountain Range (Fig. 1a) within the municipality of Caeté $\left(19^{\circ} 48^{\prime}-19^{\circ} 50^{\prime}\right.$ S; $\left.43^{\circ} 39^{\prime}-43^{\circ} 42^{\prime} \mathrm{W}\right)$, bordering the metropolitan region of Belo Horizonte (Minas Gerais ) in the Iron Quadrilateral (Fig.1b). Serra da Piedade (maximum altitude $1746 \mathrm{~m}$ ) is largely composed of itabirite, quartz, and gneiss, but areas of iron-bearing rocks (canga) appear at about $1200 \mathrm{~m}$ (Scliar 1992). Its most significant formation is canga (Brandão \& Gavilanes 1990), a Brazilian term for ironstone islands on mountaintops consisting of banded-iron formations. After intense tectonic events in the Proterozoic period, these formations were folded and underwent metamorphosis, creating itabirites (metamorphosed iron-formation composed of iron oxides, silica and quartz). Weathering throughout the Paleozoic, Mesozoic and Tertiary periods resulted in the in situ formation of canga by cementing fissures containing itabirite and hematite with other minerals, particularly limolite (Scliar 1992; Jacobi et al. 2007).

The regional climate is high-altitude subtropical (Bueno 1992). The average temperature of the coldest months (generally in July) falls below $18^{\circ} \mathrm{C}$, with the possibility of some frost at the highest altitudes, and averages for the hottest months are always below $22^{\circ} \mathrm{C}$. In relation to rainfall, Serra da Piedade shows two distinct periods: a rainy season (between November and March) and a dry season (between May and August) (Marques \& Lemos-Filho 2008). The highest rainfall occurs from December to February, with approximately half of the total annual precipitation being compressed into these few months (annual 

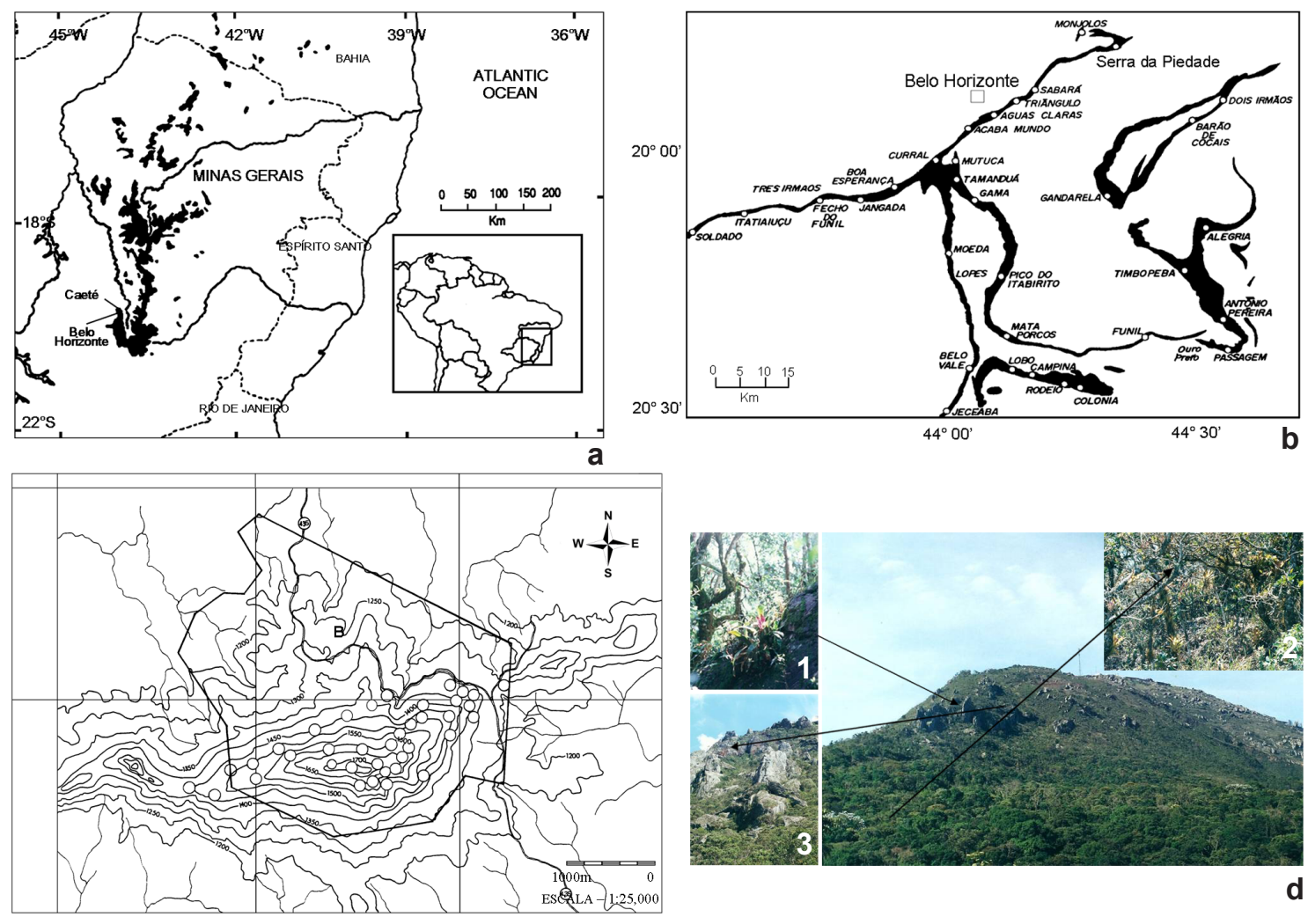

d

Figure 1 - Map showing: Espinhaço Mountain Range (EMR) a. Serra da Piedade Range, Minas Gerais, Brazil. The dark areas correspond to altitudes above $1000 \mathrm{~m}$ in EMR, adapted from Vasconcelos \& Lombardi (2001); b. areas of iron formations (itabirite, dark areas) in the Iron Quadrilateral, adapted from Pires (1995); c. location of 35 areas sampled: border of the Santuário Nossa Senhora da Piedade Reserve ( $\boldsymbol{(})$, position of the altitudinal profile $(\boldsymbol{\sim})$, and sample area (O). d. types of vegetation found inside the reserve: altitudinal cloud forest (1), montane semideciduous forest (2) and campo rupestre (3).

precipitation above $1500 \mathrm{~mm}$ ) (Bueno 1992). The waters that flow from this range form the Velhas River subbasin, which is part of the larger São Francisco River basin (Warming \& Ferri 1973). Winds are usually from the southwest and southeast, and clouds frequently cover the slopes and mountain peaks (Bueno 1992).

Floristic data was obtained from field work in 35 random areas of about $300 \mathrm{~m}^{2}$ each at wellpreserved sites along an altitudinal gradient (Fig. 1c) and from the bromeliad collections available in the BHCB, HB, R, SP herbaria. During the field work, information about habitat, geographical coordinates and approximate elevation range of each species (using a GPS) were noted to evaluate the spatial distribution of the bromeliads. Voucher specimens were photographed in their habitat and then collected, dried and included in the
BHCB herbaria. All of the study areas (with the exception of two points) were sampled within the limits of the Santuário Nossa Senhora da Piedade Reserve, which is protected as a national and state historical/artistic preservation site. The area is an Environmental Protection Area as well as a Natural Monument (according to state law n ${ }^{\circ} 15,178 / 04$ of the Minas Gerais State Constitution of 1989).

The following characteristics were noted for each bromeliad species identified during the study: (a) vegetation type in which it occurred in Serra da Piedade: semideciduous montane forest, altitudinal cloud forest, or campo rupestre (open grassy savanna and rocky outcrop vegetation) (Fig. 1d); (b) geographic distribution based on the Flora Neotropica (Smith \& Downs 1974, $1977,1979)$ and on data compiled by Versieux \& Wendt (2006): widely distributed (if the species 
is distributed over various regions of Brazil); of limited distribution (if the species is limited to a single region); or endemic (if the species occurs only in a single state); (c) occurrence in the different biomes in Minas Gerais (Versieux \& Wendt 2006; Martinelli 2007): Cerrado (which covers portions of the central western and northeastern regions of the state), Atlantic Rainforest (which occupies the eastern, southeastern and southern portions), or Caatinga (which is found in northern Minas Gerais); (d) apparent abundance at Serra da Piedade: common (appears in various vegetation types); occasional (common in only one or two vegetation types); rare (population observed in only one vegetation type and in a particular region of the mountains); or very rare (only a few individuals observed in one vegetation type); (e) conservation status of the species in Serra da Piedade (sensu IUCN 2001) and in Minas Gerais (Versieux \& Wendt 2007): least concern (LC), vulnerable (VU), endangered (EN), and critically endangered (CR). The conservation status of the bromeliad species at Serra da Piedade was determined based on direct observations following the D criteria of the IUCN (2001): very small or restricted populations - D1 (estimated population size), and populations with very restricted areas or occurring at very few sites $-\mathrm{D} 2$.

To determine similarity of the bromeliad flora at the study site in Serra da Piedade to other regions in the southern portion of the Cadeia do Espinhaço Mountain Range, species richness of bromeliads was compared to that of other localities with rocky outcrops: (a) areas dominated by quartz/ sandstone formations - Serra do Cipó (Forzza \& Wanderley 1998, Santos 2009, Coffani-Nunes et al. 2010), Serra do Ambrósio (Pirani et al. 1994), Serra da Bocaina (Pirani et al. 2003), Parque Estadual (PE) do Pico do Itambé (Versieux 2008), and Parque Estadual do Rio Preto (Versieux et al. 2010); (b) areas with quartz/sandstone and ironstone formations - Parque Estadual do Itacolomi (Coser et al. 2010) and Serra do Itabirito Range (Teixeira 2008); (c) areas dominated by ironstone formations - Parque Estadual do Rola Moça (Garçoni et al. 2010). The Jaccard similarity index and UPGMA clustering method were employed in order to identify floristic similarities between Serra da Piedade and other localities using Multivariate Statistical Package 3.0 software (MVSP). Morphospecies or unidentified taxa were excluded from the analyses.

\section{Results and Discussion}

The bromeliad flora of Serra da Piedade includes 25 species and 10 genera (Tab. 1) distributed among the subfamilies Bromelioideae (Aechmea Ruiz \& Pav., Billbergia Thunb., Bromelia L., Cryptanthus Otto \& A. Dietr. and Neoregelia L.B. Sm.), Pitcairnioideae (Dyckia Schult. \& Schult.f. and Pitcairnia L'Hér.) (Fig. 2), and Tillandsioideae (Racinaea M.A. Spencer \& L.B. Sm., Tillandsia L. and Vriesea Lindl.) (Figs. 3 and 4). The best represented subfamily in the area was Tillandsioideae ( $52 \%$ of all species). Six Tillandsioideae species were restricted to forest habitats (46\%), among which $R$. aerisincola and $V$. lubbersii were encountered exclusively in altitudinal cloud forest, and T. geminiflora and $T$. recurvata only in semideciduous montane forests (Tab. 1). The other species occurred in both forest habitats and on rocky outcrops (38\%), except for $V$. crassa and $V$. minarum, which were only encountered in campo rupestre vegetation.

Most Tillandsioideae species have ample distribution ranges in Brazil, except for $V$. crassa and $V$. pardalina, which are found in Minas Gerais and Rio de Janeiro states, and $V$. minarum, which is endemic to Minas Gerais (Tab. 1). Although most tillandsioid bromeliads are found in forest habitats in Serra da Piedade, all species can also be found on rocky outcrops in Minas Gerais (Versieux \& Wendt 2006). Vriesea crassa and V. minarum (15\%) are restricted to these areas, although $85 \%$ of tillandsioid bromeliads can be found in the Atlantic Rainforest biome (Tab. 1). Tillandsioideae species probably use forest habitats as long distance dispersal corridors that allow them to reach isolated forest areas within the open campo rupestre vegetation, principally during the dry season - which is the dispersal period for most Tillandsia and Vriesea species (Marques \& Lemos-Filho 2008). Six tillandsioid bromeliads are known to occur in the Cerrado biome (46\%) but only Tillandsia recurvata is found in the Caatinga biome (Tab. 1).

Comparing species proportions according to their subfamilies, Bromelioideae is the second richest taxon, with Cryptanthus schwackeanus and Neoregelia bahiana being restricted to rocky outcrops amidst campo rupestre vegetation in Serra da Piedade (Tab. 1). Four species occur only in forest habitats (57\%), with Bromelia antiacantha being found only in altitudinal cloud forest, and 


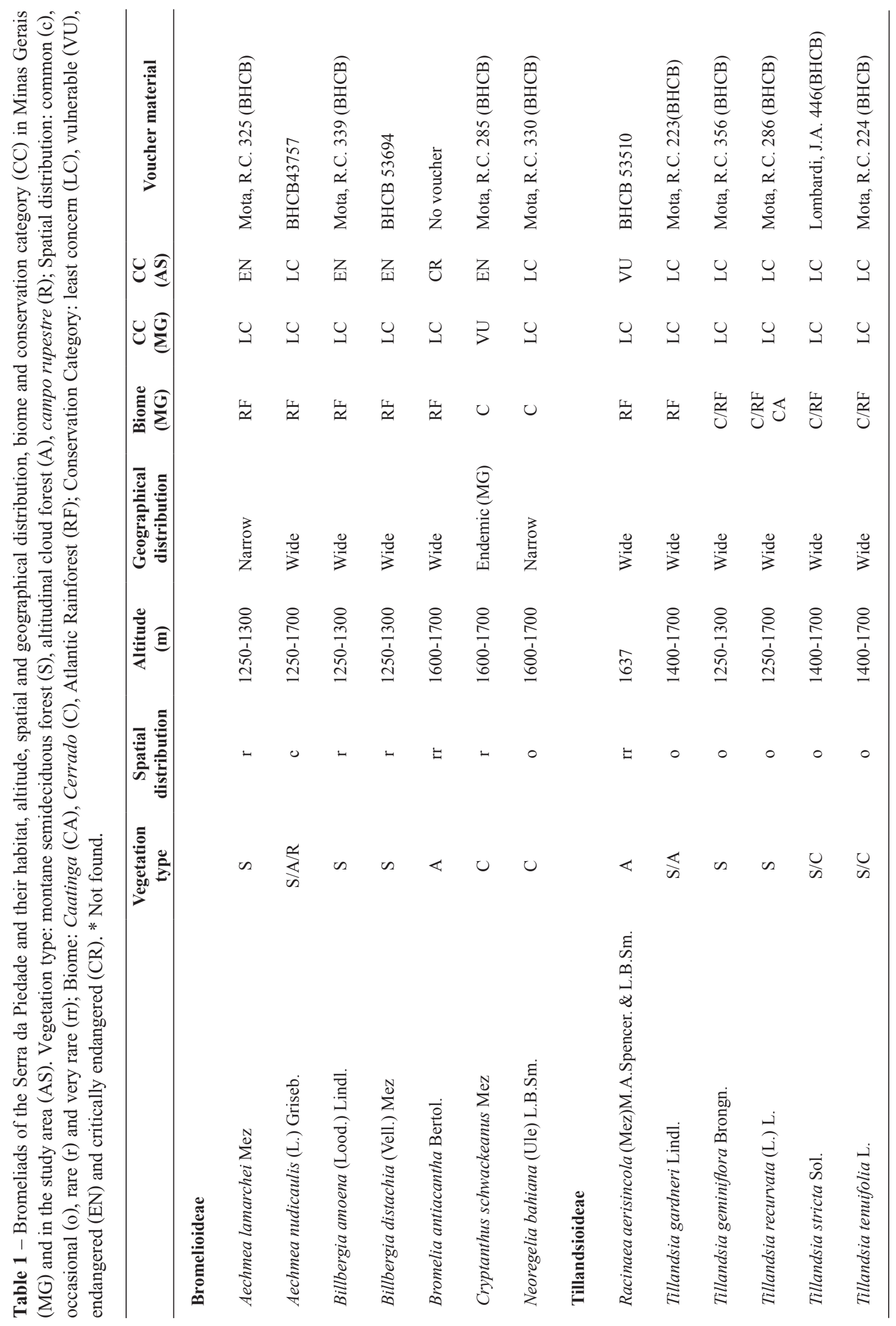




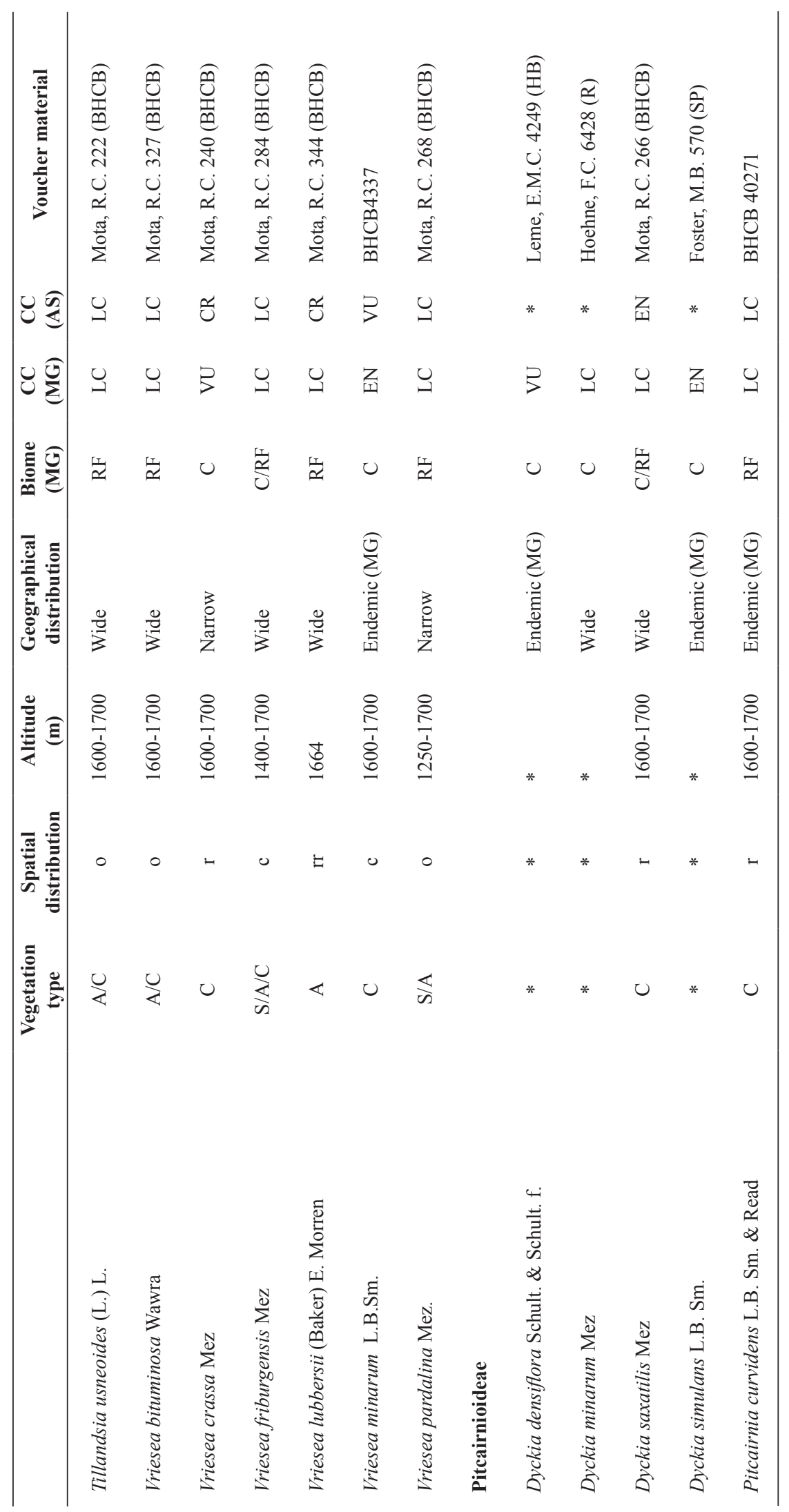



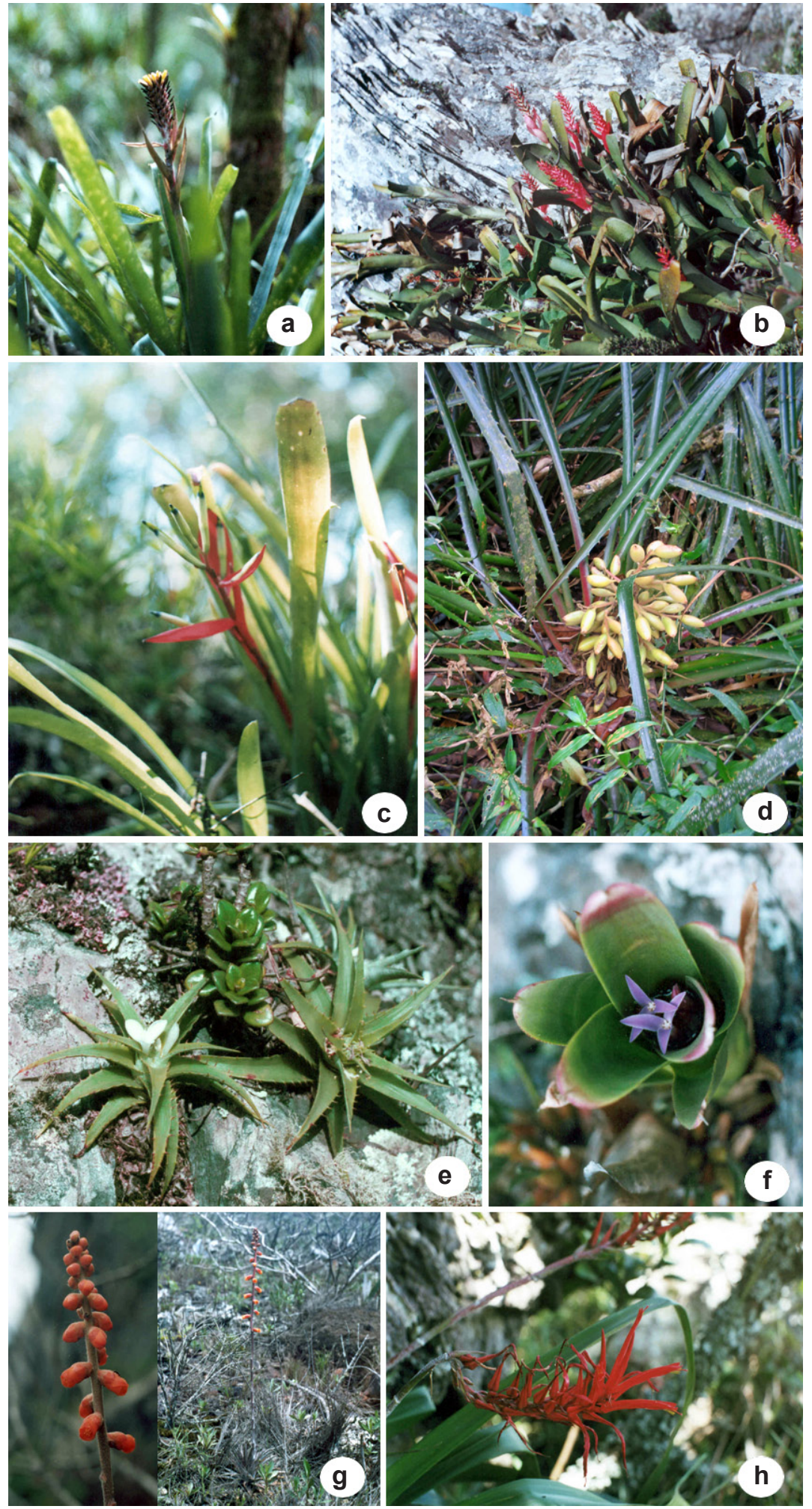

Figure 2 - Bromelioideae subfamily species - a. Aechmea lamarchei; b. A. nudicaulis; c. Billbergia amoena, d. Bromelia antiacantha; e. Cryptanthus schawackeanus; f. Neoregelia bahiana; Overall appearance of species of the Pitcairnioideae subfamily - g. Dyckia saxatilis; h. Pitcairnia curvidens. 

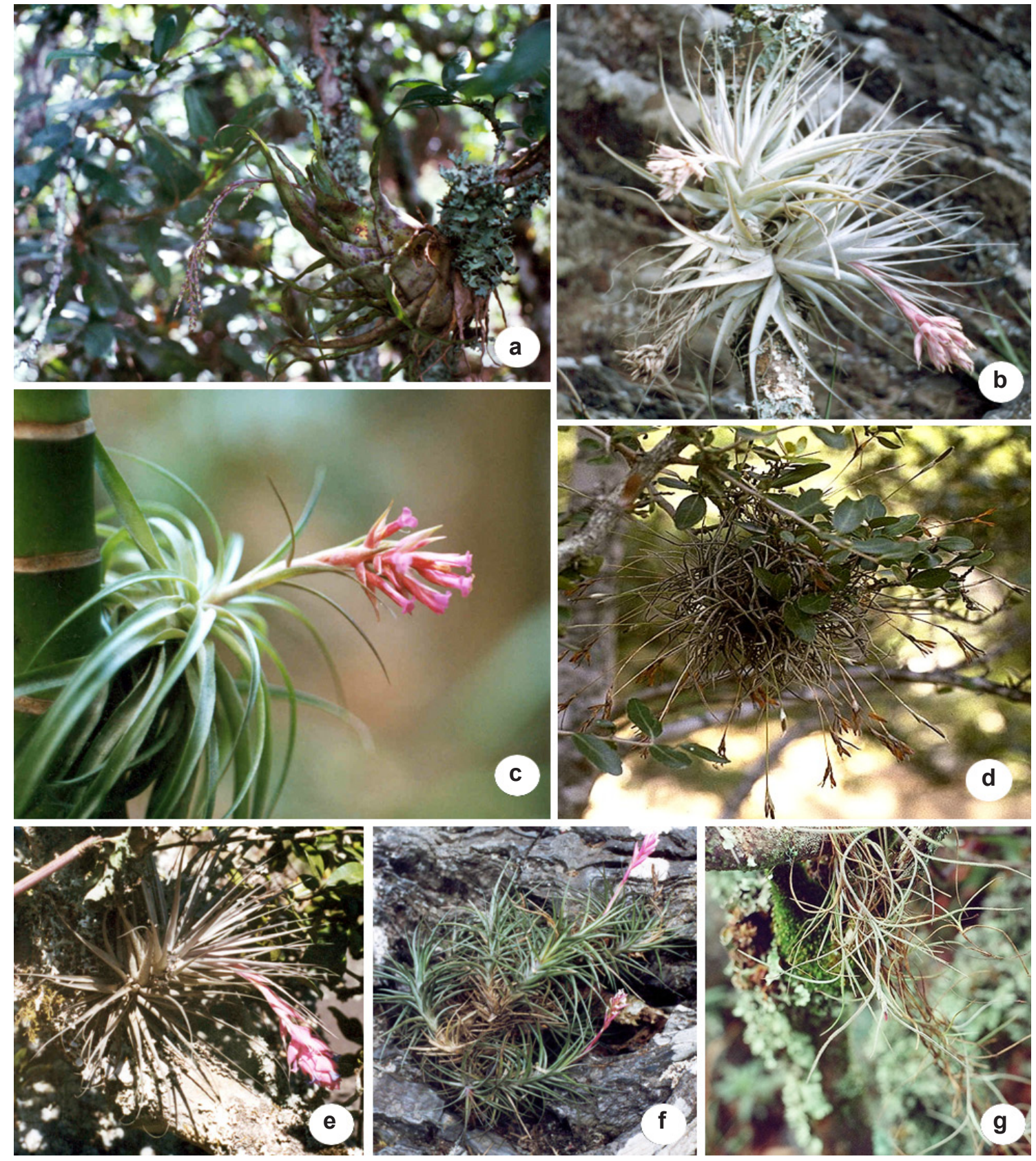

Figure 3 - Tillandsioideae subfamily species - a. Racinaea aerisincola; b. Tillandsia gardneri; c. T. geminiflora; d. T. recurvata; e. T. stricta; f. T. tenuifolia; g. T. usneoides.

Aechmea lamarchei, Billbergia amoena and B. distachia in semideciduous montane forest (Tab. 1). Aechmea nudicaulis was observed in all of the vegetation types in the mountains and is known to have wide geographic distribution throughout Brazil, together with Billbergia distachia and Bromelia antiacantha. The remaining species are endemic to Minas Gerais (Tab.1), except for
Neoregelia bahiana (which also occurs in Bahia state) and $A$. lamarchei (which also occurs in Espírito Santo state). As with the Tillandsioideae species, Bromelioideae species also predominated in forest habitats $(71 \%)$ and many can be found in the Atlantic Rainforest biome (Tab.1). The subfamily Pitcarnioideae had the fewest representatives in Serra da Piedade. Dyckia saxatilis and Pitcairnia 


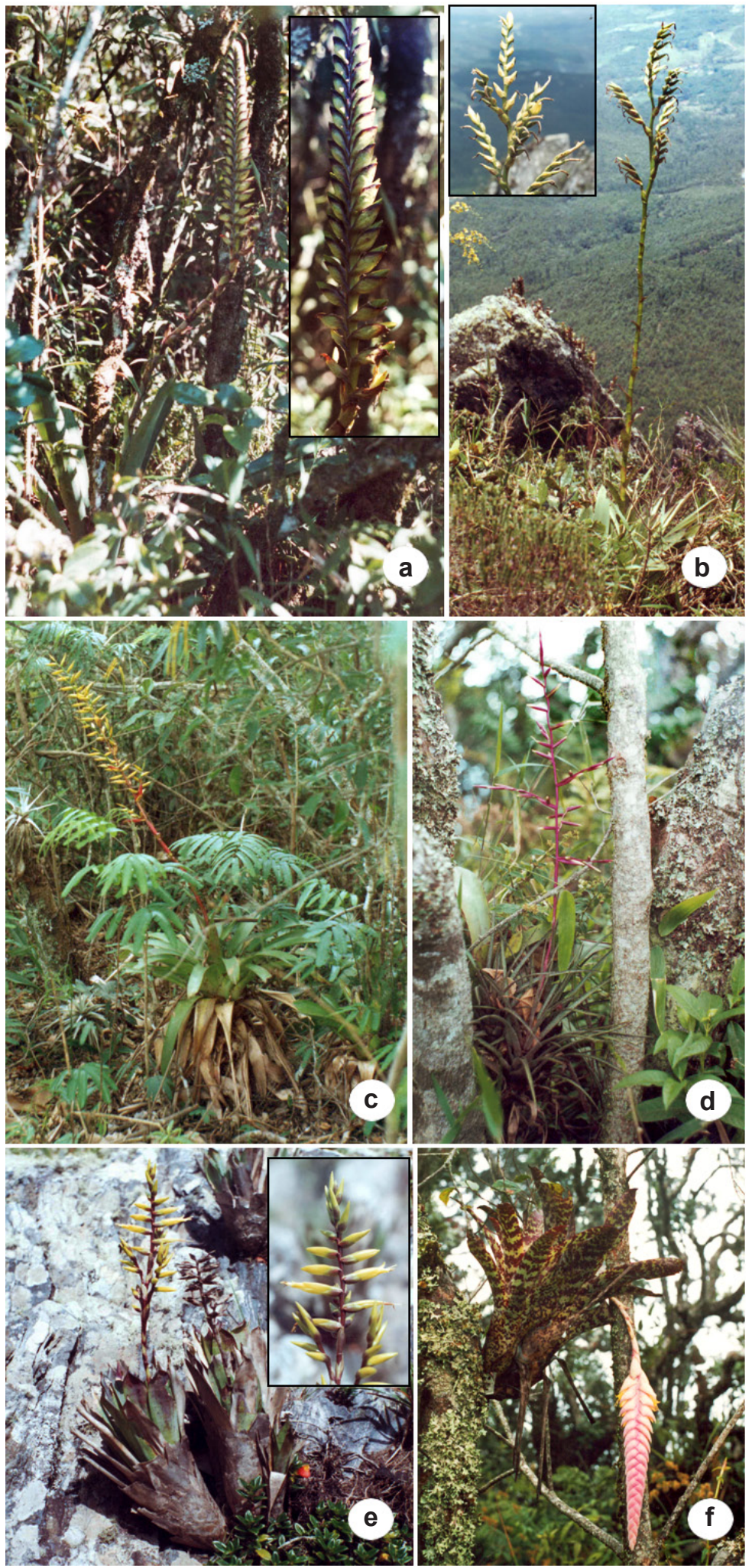

Figure 4 - Tillandsioideae subfamily species - a. Vriesea bituminosa; b. V. crassa; c. V. friburguensis; d. V. lubbersii; e. V. minarum; f. V. pardalina. 
curvidens were both found in campo rupestre sites in the mountains, but can occur in the Atlantic Rainforest biome (Tab. 1). Dyckia densiflora, D. minarum, and $D$. simulans, deposited in the HB, $\mathrm{R}$ and SP herbaria, respectively, were not found during our surveys.

Considering all of the bromeliad species encountered in Serra da Piedade, $27 \%$ were restricted to campo rupestre sites, $45 \%$ to forest habitats, and $28 \%$ were found in both habitats. As such, and regardless of a restricted occurrence or not of bromeliads in forest habitats, the majority of species (73\%) grow in semideciduous montane forest and/ or altitudinal cloud forests of Serra da Piedade, these being the sites of greatest species richness. Based on the records of Versieux \& Wendt (2006), 77\% of the Bromeliaceae species found in Serra da Piedade are also encountered in the Atlantic Rainforest and on rocky outcrops throughout Minas Gerais. Campo rupestre vegetation is traditionally associated with the Cerrado biome (Martinelli 2007), although Versieux \& Wendt (2007) pointed out that larger numbers of bromeliads can be found in Atlantic Rainforest and campo rupestre areas than in Cerrado and campo rupestre vegetation in the southern portion of the Espinhaço Mountain Range. Likewise, our data indicates that the Bromeliaceae flora of Serra da Piedade has a greater connection with the Atlantic Rainforest than with Cerrado, and that these mountains represent a typical transition zone between forest habitats and campo rupestre vegetation.

Many bromeliads have been harvested for commercial purposes from Serra da Piedade, and this history of anthropogenic pressure argues for special attention to conservation efforts in the region. In Minas Gerais, five species are considered endemic, two species endangered (Vriesea minarum and Dyckia simulans), and three species are classified as vulnerable (Cryptanthus schwackeanus, V. crassa and D. densiflora) (Tab. 1) (sensu Versieux \& Wendt 2007). In the study area, however, five bromeliads are endangered, and the situation of Bromelia antiacantha, V. lubbersii and $V$. crassa is critical - as they are only found at high-altitude sites (Tab. 1). The populations of C. schwackeanus are scattered over small rockysoil sites of campo rupestre vegetation and are therefore endangered within Serra da Piedade. Only a few individuals of $V$. crassa and $V$. lubbersii were found among the Tillandsioideae species, and they appeared to be critically threatened (Tab. 1) - suffering from heavy harvesting pressure due to their attractive rosettes and colorful flowers (A. Marques, personal observation). Small populations of Racinaea aerisincola and $V$. minarum are vulnerable, principally due to the fact that their distribution is restricted to altitudinal cloud forests and campo rupestre vegetation, respectively, in

Table 2 - Similarity values between the inventoried areas for the Bromeliaceae family in the Minas Gerais State (values presented as percentage).

\begin{tabular}{llllllllll}
\hline & $\begin{array}{c}\text { Serra da } \\
\text { Piedade }\end{array}$ & $\begin{array}{c}\text { PE do } \\
\text { Itacolomi }\end{array}$ & $\begin{array}{c}\text { Serra do } \\
\text { Cipó }\end{array}$ & $\begin{array}{c}\text { Serra do } \\
\text { Ambrósio }\end{array}$ & $\begin{array}{c}\text { Serra da } \\
\text { Bocaina }\end{array}$ & $\begin{array}{c}\text { PE Rola } \\
\text { Moça }\end{array}$ & $\begin{array}{c}\text { PE } \\
\text { Itambé }\end{array}$ & $\begin{array}{c}\text { Serra de } \\
\text { Itabirito }\end{array}$ & $\begin{array}{c}\text { PE do Rio } \\
\text { Preto }\end{array}$ \\
\hline $\begin{array}{l}\text { Serra da } \\
\text { Piedade }\end{array}$ & $*$ & $*$ & $*$ & $*$ & $*$ & $*$ & $*$ & $*$ & $*$ \\
$\begin{array}{l}\text { PE do } \\
\text { Itacolomi }\end{array}$ & 18.9 & $*$ & $*$ & $*$ & $*$ & $*$ & $*$ & $*$ & $*$ \\
$\begin{array}{l}\text { Serra } \\
\text { do Cipó }\end{array}$ & 23.8 & 16.1 & $*$ & $*$ & $*$ & $*$ & $*$ & $*$ & $*$ \\
$\begin{array}{l}\text { Serra do } \\
\text { Ambrósio }\end{array}$ & 10.0 & 3.8 & 13.0 & $*$ & $*$ & $*$ & $*$ & $*$ & $*$ \\
$\begin{array}{l}\text { Serra da } \\
\text { Bocaina }\end{array}$ & 13.5 & 9.1 & 16.7 & 19.0 & $*$ & $*$ & $*$ & $*$ & $*$ \\
$\begin{array}{l}\text { PE } \\
\text { Rola Moça }\end{array}$ & 20.5 & 13.9 & 15.4 & 3.4 & 11.4 & $*$ & $*$ & $*$ & $*$ \\
PE Itambé & 21.2 & 6.3 & 13.3 & 0 & 10.3 & 12,1 & $*$ & $*$ & $*$ \\
$\begin{array}{l}\text { Serra de } \\
\text { Itabirito }\end{array}$ & 20.7 & 16.0 & 16.7 & 5.9 & 12.5 & 23.1 & 25.0 & $*$ \\
$\begin{array}{l}\text { PE do Rio } \\
\text { Preto }\end{array}$ & 20.4 & 8.2 & 22.5 & 10.5 & 27.5 & 9,8 & 14.0 & $*$ & $*$ \\
\hline
\end{tabular}


Serra da Piedade (Tab. 1). Vriesea minarum is under constant threat of extinction in Minas Gerais due to the fact that its populations are restricted to canga sites that are mined for iron ore. Versieux (2011) stressed the necessity to protect these areas officially and to develop proactive guidelines that would guarantee the conservation of this species before authorizing mining activities. No specimens of $D$. densiflora, D. minarum, or D. simulans were encountered in any of the surveys.

In comparing the bromeliad flora of Serra da Piedade to other localities (Tab. 2), only the flora of Serra do Cipó showed greater species richness (Fig. 5). Jaccard similarity indices of the different sites varied from 0 to $25 \%$ (Tab. 2 ). According to cluster analyses and similarity indices, the bromeliad flora of Serra da Piedade is more similar to Serra do Cipó (23.8\%), followed by Parque Nacional do Itambé (21.2\%), Serra do Itabirito, PE do Rola Moça and PE do Rio Preto (20.7; 20.5 and $20.4 \%$ respectively) sites - which are

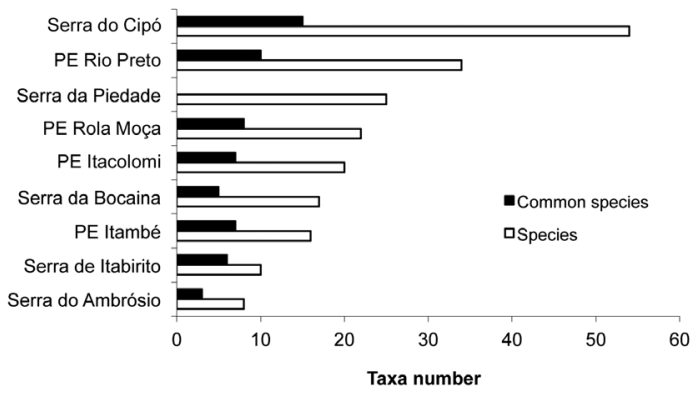

Figure 5 - Comparative data of Bromeliaceae taxa richness and common species for the Serra da Piedade Range.

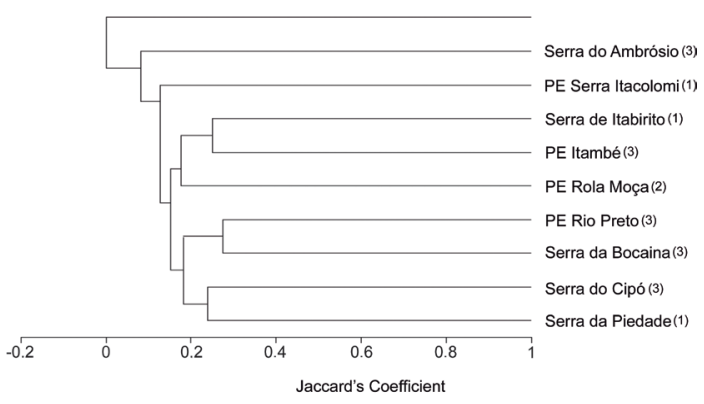

Figure 6 - Dendrogram showing similarity between the inventoried areas at the Espinhaço Mountain Range in Minas Gerais based only Bromeliaceae taxa. (1) canga, (2) quartz/canga (3) quartz substrate. located in different regions of the Iron Quadrilateral on ironstone outcrops or in quartz formations. In spite of the fact that the bromeliad flora of Serra da Piedade appears in the cladogram as a member of the group of quartz/sandstone localities (Fig. 6), floristic similarity was actually very low. These values reinforce the idea of floristic individuality in each area is independent of the exact composition of the substrate. Serra do Cipó (15 species), PE Rio Preto (10 species), followed by PE Rola Moça ( 8 species), PE Itacolomi and PE do Itambé (7 species) had proportionally fewer species in common with Serra da Piedade, which explains the dissimilarities of these regions (Fig. 5). Similarity values below $50 \%$ in terms of the bromeliad flora in diverse areas of the Espinhaço Mountain Range were reported by Versieux et al. (2010). According to Versieux \& Wendt (2007), this same pattern was observed with all of the bromeliads in Minas Gerais, and is apparently due to the presence of elevated numbers of endemic species or species with restricted geographic distribution. Low floristic similarities even in neighboring locations have previously been reported in the Espinhaço Mountain Range (Haley 1995; Zappi et al. 2003; Conceição et al. 2007; Azevedo \& Berg 2007; Mourão \& Stehmann 2007; Rapini et al. 2008; Alves \& Kolbek 2009).

Special attention should be given to Serra da Piedade in the Iron Quadrilateral, as it is located very close to densely inhabited urban centers and is at risk of environmental degradation, mining, wildfires and vandalism, and its diversity (including altitudinal cloud and semideciduous montane forests, open grasslands, and rocky outcrops) should be protected. We believe that the information concerning species richness, endemism, and the conservation status of the bromeliads described in this text will argue for proactive measures to protect and conserve this region.

\section{Acknowledgements}

This paper is part of the $\mathrm{PhD}$ thesis of ARM, and was undertaken at the Graduate Program in Ecology, Conservation and Wild Life Management at the Federal University of Minas Gerais. We acknowledge grant support from CNPq (National Council for Scientific and Technological Development) and Fapemig (Minas Gerais Research Support Foundation) and gratefully thank Leonardo M. Versieux for reviewing and confirming some of the bromeliad species identifications. 


\section{References}

Alves, R.J.V. \& Kolbek, J. 2009. Can campo rupestre vegetation be floristically delimited based on vascular plant genera? Plant Ecology 207: 67-79.

Alves, R.J.V.; Cardin, L. \& Kropf, M.S. 2007. Angiosperm disjunction "campos rupestres-restingas" - a reevaluation. Acta Botanica Brasilica 21: 675-685.

Azevedo, C.O. \& Berg, C. 2007. Análise comparativa de áreas de campos rupestres da Cadeia do Espinhaço (Bahia e Minas Gerais) baseada em espécies de Orchidaceae. Sitientibus 7: 199-210.

Brandão, M. \& Gavilanes, M.L. 1990. Mais uma contribuição para o conhecimento da Cadeia do Espinhaço em Minas Gerais (Serra da Piedade) - II. Daphne 1: 26-43.

Bueno, M.E.T. 1992. Geografia. In: Duarte, R.H. (coord.). Serra da Piedade. Companhia Energética de Minas Gerais - CEMIG, Belo Horizonte. Pp. 57-75.

Conceição, A.A.; Pirani, J.R. \& Meirelles, S.T. 2007. Floristics, structure and soil of insular vegetation in four quartzite-sandstone outcrops of Chapada Diamantina, Northeast Brazil. Revista Brasileira de Botânica 30: 641-655.

Coffani-Nunes, J.V.; Versieux, L.M.; Wanderley, M.G.L. \& Pirani, J.R. 2010. Flora da Serra do Cipó, Minas Gerais: Bromeliaceae - Tillandsioideae. Boletim de Botânica da USP 28: 35-54.

Coser, T.S.; Paula, C.C. de \& Wendt, T. 2010. Bromeliaceae Juss. nos campos rupestres do Parque Estadual do Itacolomi, Minas Gerais, Brasil. Rodriguésia 61: 261-280.

Forzza, R.C. \& Wanderley, M.G.L. 1998. Flora da Serra do Cipó, Minas Gerais: Bromeliaceae Pitcairnoideae. Boletim de Botânica da USP 17: 255-270.

Garçoni, E.A.E.; Paula, C.C. \& Costa, A.F. 2010. Bromeliaceae do Parque Estadual da Serra RolaMoça, Minas Gerais. Rodriguésia 61: 467-490.

Giulietti, A.M.; Menezes, N.L.; Pirani, J.R.; Marico, M. \& Wanderley, M.G.L. 1987. Flora da Serra do Cipó, Minas Gerais: caracterização e lista das espécies. Boletim de Botânica da USP 9: 1-151.

Giulietti, A.M.; Pirani, J.R. \& Harley, R.M. 1997. Espinhaço range region-eastern Brazil. In: Davis, S.D.; Heywood, V.H.; Herrera-Mac Bryde, O.; Villa-Lobos, J. \& Hamilton, A.C. (eds.). Centers of plant diversity: a guide and strategy for their conservation. WWF/UCN Publications Unit., Cambridge. Pp. 397-404.

Giulietti, A.M.; Harley, R.M.; Queiroz, L.P.; Wanderley, M.G.L. \& Pirani, J.R. 2000. Caracterização e endemismos nos campos rupestres da cadeia do Espinhaço. In: Cavalcanti, T.B. \& Walter, B.M. (eds.). Tópicos atuais em botânica. Embrapa Recursos Genéticos e Biotecnologia, Sociedade de Botânica do Brasil, Brasília. Pp. 311-318.
Giulietti, A.M.; Harley, R.M.; Queiroz, L.P.; Wanderley, M.G.L. \& Van Den Berg, C. 2005. Biodiversity and conservation of plants in Brazil. Conservation Biology 19: 632-639.

Harley, R.M. 1995. Introduction. In: Stannard, L.B.; Harvey, Y.B. \& Harley, R.M. (eds.). Flora of the Pico das Almas, Chapada Diamantina - Bahia, Brasil. Royal Botanic Gardens, Kew. Pp. 43-76.

IUCN. 2001. IUCN red list categories and criteria: version 3.1 IUCN species survival commission. IUCN, Gland Switzerland - Cambrigde.

Jacobi, C.M.; Carmo, F.F.; Vicent, R.C. \& Stehmann, J.R. 2007. Plant communities on ironstone outcrops: a diverse and endangered Brazilian ecosystem. Biodiversity and Conservation 16: 2185-2200.

Jacobi, C.M. \& Carmo, F.F. 2008. Diversidade dos campos rupestres ferruginosos no Quadrilátero Ferrífero, MG. Megadiversidade 4: 25-32.

Jacobi, C.M.; Carmo, F.F. \& Campos, I.C. 2011. Soaring extinction threats to endemic plants in Brazilian metal-rich regions. AMBIO 40: 540-543.

Marques, A.R. \& Lemos-Filho, J.P. 2008. Fenologia reprodutiva de espécies de bromélias na Serra da Piedade, MG, Brasil. Acta Botanica Brasilica 22: 417-424.

Martinelli, G. 2007. Mountain biodiversity in Brazil. Revista Brasileira de Botânica 30: 587-597.

Medina, E. 1990. Eco-fisiologia y evolucion de las Bromeliaceae. Boletin de la Academia Nacional de Ciências, Cordoba 59: 1-100.

MMA - Ministério do Meio Ambiente. 2000. Avaliação e ação prioritárias para a conservação da biodiversidade da Mata Atlântica e Campos Sulinos. Conservation International do Brasil, Fundação SOS Mata Atlântica, Fundação Biodiversitas, Instituto de Pesquisas Ecológicas, SMA de SP e SEMAD/ Instituto Estadual de Florestas - MG, Brasília. 40p.

Mourão, F.A. \& Stehmann, J.R. 2007. Levantamento da flora dos campos rupestres sobre canga hematítica couraçada remanescente na Mina do Brocutu, Barão de Cocais, Minas Gerais, Brazil. Rodriguésia 58: 775-786.

Pirani, J.R.; Giulietti, A.M.; Mello-Silva, R. \& Meguro, M. 1994. Checklist and patterns of geographic distribution of vegetation of the Serra do Ambrósio, Minas Gerais, Brazil. Revista Brasileira de Botânica 17: 133-147.

Pirani, J.R.; Mello-Silva, R. \& Giulietti, A.M. 2003. Flora de Grão-Mogol, Minas Gerais, Brasil. Boletim de Botânica da USP 21: 1-24.

Pires, F.R.M. 1995. Texturad and mineralogical variations during metamorphism of the Proterozoic Itabira iron formation in the Quadrilátero Ferrífero, Minas Gerais, Brasil. Anais da Academia Brasileira de Ciências 67: 77-105. 
Rapini, A.; Ribeiro, P.L.; Lambert, S. \& Pirani, J.R. 2008. A flora dos campos rupestres da Cadeia do Espinhaço. Megadiversidade 4: 1-2.

Rizzini, C.T. 1997. Tratado de fitogeografia do Brasil. Âmbito Cultural Edições, Rio de Janeiro. 747p.

Sano, M. \& Almeida, S. P. 1998. Cerrado: ambiente e flora. EMBRAPA, Planaltina, DF. 556p.

Santos, A. L. 2009. Bromelioideae (Bromeliaceae) na Serra do Cipó, Minas Gerais, Brasil. Dissertação de Mestrado. Instituto de Botânica da Secretaria de Estado do Meio Ambiente, São Paulo. 78p.

Scarano, F.R. 2007. Rock outcrop vegetation in Brazil: a brief overview. Revista Brasileira de Botânica 30: 561-568.

Scliar, C. 1992. Geologia. In: Duarte, R.H. (coord.). Serra da Piedade. Companhia Energética de Minas Gerais - CEMIG, Belo Horizonte. Pp. 77-97.

Smith, L.B. \& Downs, R.J. 1974. Pitcairnioideae (Bromeliaceae). Flora Neotropica Monograph. $\mathrm{N}^{\circ}$. 14, Part 1. Hafner Press, New York. 658p.

Smith, L.B. \& Downs, R.J. 1977. Tillandsioideae (Bromeliaceae). Flora Neotropica Monograph. No. 14, Part 2. Hafner Press, New York. Pp. 659-1492.

Smith, L.B. \& Downs, R.J. 1979. Bromelioideae (Bromeliaceae). Flora Neotropica Monograph. $\mathrm{N}^{\circ}$. 14, Part 3. Hafner Press, New York. Pp. 1493-2142.

Teixeira, W.A. 2008. A flórula rupestre do Pico do Itabirito e análise biogeográfica em relação à Cadeia do Espinhaço. Tese de Doutorado. Universidade Federal de Minas Gerais. 113p.

Teixeira, W.A. \& Lemos-Filho, J.P. 2002, Fatores edáficos e a colonização de espécies lenhosas em uma cava de mineração de ferro em Itabirito, Minas Gerais. Revista Árvore 26: 25-33.
Warming, E. \& Ferri, M.G. 1973. Lagoa Santa e a vegetação dos cerrados brasileiros. EDUSP, SP e Editora Itatiaia Ltda, Belo Horizonte. 404p.

Vasconcelos, M.F. \& Lombardi, J.A. 2001. Hummingbirds and their flowers in the campos rupestres of southern Espinhaço Range, Brazil. Melopsittacus 4: 3-30.

Versieux, L.M. 2008. Checklist and one new species of Bromeliaceae from Pico do Itambé, Minas Gerais, Brazil. Botanical Journal of the Linnean Society 158: 709-715.

Versieux, L.M. 2011. Brazilian plants urgently needing conservation : the case of Vriesea minarum (Bromeliaceae). Phytotaxa 28: 35-49.

Versieux, L.M. \& Wendt, T. 2006. Checklist of Bromeliaceae of Minas Gerais, Brazil, with notes on taxonomy and endemism. Selbyana 27: 107-146.

Versieux, L.M. \& Wendt, T. 2007. Bromeliaceae diversity and conservation in Minas Gerais state, Brazil. Biodiversity and Conservation 16: 2989-3009.

Versieux, L.M.; Wendt, T.; Louzada, R.B. \& Wanderley, M.G.L. 2008. Bromeliaceae da Cadeia do Espinhaço. Megadiversidade 4: 98-110.

Versieux, L.M.; Louzada, R.B.; Viana, P.L.; Mota, N. \& Wanderley, M.G.L. 2010. An illustrated checklist of Bromeliaceae from Parque Estadual do Rio Preto, Minas Gerais, Brazil, with notes on phytogeography and one new species of Cryptanthus. Phytotaxa 10: 1-6.

Zappi, D.; Lucas, E.; Stannard, B.L.; Lughadha, E.N.; Pirani, J.R.; Queiroz, L.P.; Atkins, S.; Hind, N.; Giulietti, A.M.; Harley, R.M.; Mayo, S.J. \& Carvalho, A.M. 2003. Lista das plantas vasculares de Catolés, Chapada Diamantina, Bahia. Boletim de Botânica da Universidade de São Paulo 21: 345-398. 